\title{
РАСПОРЯЖЕНИЕ И УПРАВЛЕНИЕ ИМУЩЕСТВОМ В ДОГОВОРАХ ДОВЕРИТЕЛЬНОГО УПРАВЛЕНИЯ
}

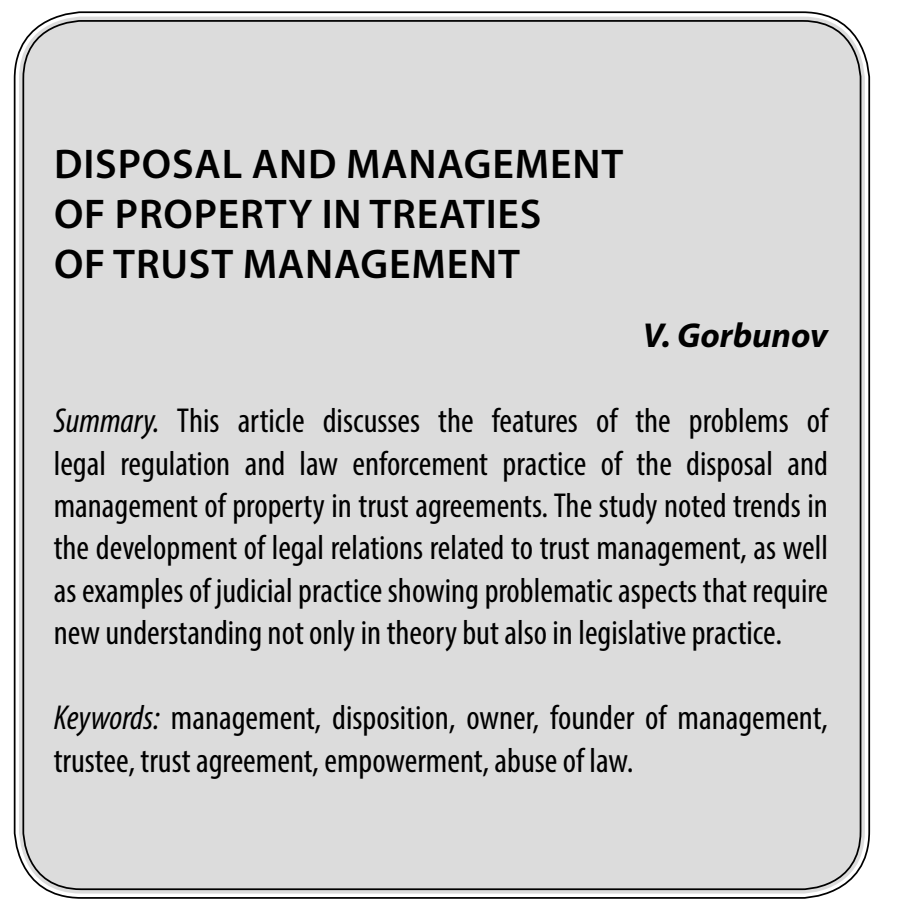

O бращение к теме правового регулирования распоряжения и управления имуществом в договорах доверительного управления связано как с повышенным спросом на институт доверительного управления, так и наличием проблем, как законодательного, так и правоприменительного механизма.

В глобальных условиях развития, институт доверительного управления выступает механизмом эффективного управления имуществом.

Стоит признать, что в теоретико-методологическом аспекте, институт доверительного управления достаточно изучен. Однако и на сегодняшний день, существует ряд дискуссий, касающихся таких вопросов как: понятие управления и распоряжения имуществом в договоре доверительного управления, особенности правомочий доверительного управляющего, а также существует множество проблем практического плана, связанных с правоприменением. Кроме этого, в законодательство вносятся постоянно изменения и дополнения, что требует новой оценки.

Современное развитие цивилистической науки напрямую связано с необходимостью новых теоретико-методологических подходов к проблемам гражданского

\author{
Горбунов Владимир Александрович \\ Аспирант, Российская государственная академия \\ интеллектуальной собственности \\ vldgorb@gmail.com
}

Аннотация. В данной статье рассматриваются особенности проблем правового регулирования и правоприменительной практики распоряжения и управления имуществом в договорах доверительного управления. В исследовании отмечены тенденции развития правоотношений, связанных с доверительным управлением, а также на примерах судебной практики показаны проблемные аспекты, требующие нового осмысления не только в теории, но и законодательной практике.

Ключевые слова: управление, распоряжение, собственник, учредитель управления, доверительный управляющий, договор доверительного управления, расширение полномочий, злоупотребление правом.

права на основе потребностей времени, существующих коллизий и достижений в праве.

Институт доверительного управления в гражданском праве является одним из значимых элементов реализации прав собственника на эффективное управление имуществом. Именно доверительное управление позволяет реализовать собственнику имущества различные цели. Так, например, наличие профессиональных навыков доверительного управляющего является важным элементом эффективного управления. Кроме того, собственник избавляется от бремени содержания.

Таким образом, стоит выделить ряд преимуществ договора доверительного управления, в частности:

собственник:

- освобождается от расходов по содержанию имущества;

- получает доход от использования недвижимости;

- сохраняет право собственности на имущество.

управляющий:

- получает вознаграждение за услуги;

- не обременен ответственностью, связанной с получением права собственности на объект; 
- может использовать имущество как для личных целей, так и для ведения бизнеса, при наличии соответствующих условий в договоре [6].

Важное значение в реализации доверительного управления имуществом принадлежит управляющему, что создает необходимость разграничения понятия полномочий собственника имущества, и управляющего. Также возникает вопрос о разграничении таких понятий как управление и распоряжение имуществом по договору доверительного управления. Во многом, институт доверительного управления обусловлен необходимостью эффективного управления имуществом, на профессиональной основе.

Правовой основой для регулирования института доверительного управления выступают нормы Гражданского кодекса Российской Федерации (далее ГК РФ) главы 53 [1]. Согласно ст. 1012 ГК РФ договор доверительного управления - это договор, между двумя сторонами, одной из которой выступает учредитель управления, а другой доверительной управляющий, устанавливающий обязательства по доверительному управлению имуществом.

В рамках правового регулирования договора доверительного управления, на практике необходимо отличать процесс управления и распоряжения имуществом.

В договорах доверительного управления собственник остаётся собственником, но передаёт часть правомочий по распоряжению в согласованных пределах доверительному управляющему. Однако, стоит отметить, что в судебной практике существует ряд проблем, например, когда собственников несколько и, когда возникает необходимость защиты прав отдельного собственника.

Так, например, Толмачевские ГЭС обратились в суд за передачей из доверительного управления доли К «КамГЭК» общество, которое явилось доверительным управляющим. Однако суд при рассмотрении данного дела указал, что не может удовлетворить требования собственника, поскольку договор доверительного управления, который был заключен 24.05.2002 является обязательством со множеством лиц на стороне учредителя управления. При этом, согласно договору, речь идет о долевой собственности и выделение отдельной доли в рамках защиты права невозможно. Это связано с тем, что сам объект, который был передан в доверительное управление каскад ГЭС на реке Толмачева является неделимым [2].

Доверительное управление согласно нормам главы 53 ГК РФ не ведет к потере прав у собственника, а так- же нормативно-правовых оснований для расширения прав долевого управляющего. Однако в последние годы, по сравнению с прежним периодом развития наметилась тенденция к расширению правомочий, в силу:

1. активного развития института доверительного управления, и получения определенного опыта многими компаниями на рынке доверительного управления, а значит и возможностью злоупотребления правами;

2. проблемами неурегулированности некоторых вопросов, как на стадии заключения договоров, так и на законодательном уровне.

Так, например, в правоприменительной практике зачастую стали встречаться споры, связанные с присвоением прибыли компанией, имеющей правомочия по доверительному управлению.

Так, например, Администрация г. Читы обратилась в суд к ПАО «Межрегиональная распределительная сетевая компания Сибири» о взыскании прибыли по договору доверительного управления имуществом. Сумма иска составила 178,5 млн. руб. Согласно договору доверительного управления объектом доверительного управления явились «Городские электрические сети». Прибыль на основании договора распределялась следующим образом - 80\% в бюджет города Читы и 20\% управляющей компании. В 2014 г. управляющая организация указала прибыль - 0 руб. Администрация г. Читы на основании сведений регулирующего органа, обратилась в суд. При этом, как выяснилось в ходе судебного заседания

«Межрегиональная распределительная сетевая компания Сибири» включила в расходы по сомнительным долгам сумму в размере 205584134 руб. 45 коп. [3]

По мнению И. В. Маштакова, при выходе доверительного управляющего за пределы установленных ограничений распоряжения имуществом, стоит говорить о гражданских правонарушениях [7].

В правоприменительной практике к злоупотреблению правом, помимо недобросовестности, относят и так называемое «неразумное поведение», то есть, такое поведение, которое не соответствует обычному гражданскому обороту или обычаям делового поведения, а также сложившимся подходам к предпринимательскому риску [4].

Так, например, Ш. Обратился в суд к Д. о взыскании денежных средств по договору доверительного управления имуществом в размере 564 753,29 рубля, расходов по уплате госпошлины в размере 8847,53 руб., расходов по оплате нотариальных услуг. 
Между Ш. и Д. был заключен договор доверительного управления имуществом № 12-08 (далее по тексту - Договор). Согласно преамбуле Договора Ш. является «Учредителем», а Д. является «Доверительным управляющим». Договор был расторгнут, в связи с тем, что Д. свои обязательства по оплате доходов от доверительного управления в пользу истца не исполнила. В соответствии с приложенным прогнозным бюджетом ответчица обязана оплатить истцу доходы в размере 564753,29 руб. Кроме того, ответчица также не исполнила своих обязательств по предоставлению отчета, что было предусмотрено договором [5].

Однако суд не удовлетворил исковые требования Ш. указав, что договор был заключен с физическим ли- цом - Д., которая индивидуальным предпринимателем не является. Также в суд не представлены доказательства о предпринимательской деятельности.

В данном случае, данный пример наглядно показывает, с одной стороны злоупотреблением правом, а с другой недействительность договора доверительного управления, на что указал суд.

В этом смысле, стоит указать на тенденцию увеличения роли доверительного управляющего по договорам доверительного управления в плане осуществления различного рода значимых финансовых и иных действий, которые могут привести к существенному ущербу для собственника имущества.

\section{ЛИТЕРАТУРА}

1. Гражданский кодекс Российской Федерации (часть вторая) от 26.01.1996 № 14-Ф3 (ред. от 18.03.2019, с изм. от 03.07.2019) // СЗ РФ 1996. № 5. ст. 410.

2. Определение Верховного Суда РФ от 29.11.2019 № 303-ЭС19-21548 по делу № А24-5040/2016 // СПС Консультант плюс 2020

3. Постановление Арбитражного суда Восточно-Сибирского округа от 10.11.2017 N Ф02-5912/2017 по делу N A78-7818/2015 // СПС Консультант плюс 2020

4. Постановление Пленума Верховного Суда РФ от 23.06.2015 № 25 «0 применении судами некоторых положений раздела I части первой Гражданского кодекса Российской Федерации» // СПС Консультант Плюс 2020.

5. Решение Октябрьского районного суда г. Томска № 2-3357/20162-3357/2016 M-4251/2016 M-4251/2016 от 19 декабря 2016 г. по делу № 2-3357/2016 // [Электронный ресурc]: https://sudact.ru/regular/doc/iVbw90skYlgX/

6. Любогощинская А. Передача собственности в доверительное управление в 2020 году // [Электронный ресурс]: https://online-buhuchet.ru/peredachasobstvennosti-v-doveritelnoe-upravlenie/

7. Маштаков И. В. Гражданские правонарушения, возникающие при исполнении договора доверительного управления имуществом по гражданскому законодательству РФ // Вестник Самарской гуманитарной академии Серия Право 2017. №№ 1-2. С. 36-42. 